\title{
IAMJ
}

INTERNATIONAL

AYURVEDIC

MEDICAL JOURNAL

\section{COMPARATIVE CLINICAL STUDY OF SHUNTHYAADI SNEHA YOGA NASYA OVER KSHAVATHU ROGA W.S.R. TO ALLERGIC RHINITIS BASED ON SNEHA MEDIA}

\author{
Shreeganesh Aithal ${ }^{1}$, Laxmi. B. Kurle ${ }^{2}$ \\ ${ }^{1}$ PG Scholar, T.G.A.M.C \& H Ballari, Karnataka, India \\ ${ }^{2}$ Associate Professor, T.G.A.M.C \& H Ballari, Karnataka, India
}

Corresponding Author: ganesh.aithal5@gmail.com

https://doi.org/10.46607/iamj0409102021

(Published Online: October 2021)

Open Access

(C) International Ayurvedic Medical Journal, India 2021

Article Received: 24/09//2021 - Peer Reviewed: 06/10/2021 - Accepted for Publication: 07/10/2021

\section{Check for updates}

\begin{abstract}
Shunthyaadi Sneha Yoga which is a Sneha Kalpana developed with Ghrita and Taila Paka method containing ingredients which are Kshavathu hara and indicated specifically in Kshavathu Roga. In Ayurveda, Kshavathu is a symptom of many diseases and at the same time a separate disease entity. The literal meaning of Kshavathu is sneezing and is the main symptom of Allergic Rhinitis and both share similar etiological factors. Allergic rhinitis is an atopic disease characterised by symptoms of nasal congestion, clear rhinorrhea, sneezing, postnasal drip, and nasal pruritis. It is an inflammatory disorder of the nasal mucosa induced by allergen exposure triggering IgEmediated inflammation. Around $20-30 \%$ of the Indian population suffers from allergic rhinitis and that $15 \%$ develop asthma. In the present study, an attempt has been made to compare the efficacy of Shunthyaadi Taila Nasya and Shunthyaadi Ghrita Nasya designed in two groups comprising fifteen patients each and analysed with parametric and non-parametric tests. Both the groups showed remarkable results in the management of Kshavathu.
\end{abstract}

Keywords: Kshavathu, Shunthyaadi Sneha Yoga, Shunthyaadi Taila, Shunthyaadi Ghrita, Nasya, 


\section{INTRODUCTION}

Allergic Rhinitis is a disease pertaining Nose induced by an immunoglobin $\mathrm{E}(\mathrm{IgE})$-mediated inflammatory reaction after allergic exposure of the membranes lining the nose $\mathrm{e}^{1}$ and is characterized by watery nasal discharge, Nasal congestion and sneezing ${ }^{2}$. In day to day, medical practice Allergic rhinitis is one of the most common diseases that we come across. It adversely affects the quality of life, psychology, lifestyle and impacts work productivity. It is an acute IgE mediated, type-1 hypersensitivity reaction of nasal mucosa in response to an antigenic substance (allergen) associated with episodic attacks of sneezing, watery rhinorrhea and watering of the eyes. ${ }^{4}$ Allergic rhinitis constitutes more than $50 \%$ of all allergies in India and its incidence is steadily increasing worldwide. The word meaning of Kshavathu is sneezing. Due to our modern lifestyle and increased air pollution invited such diseases and which is also disgusted by Viruddha Ahara Vihara Sevana. Regarding allergy, there is no direct reference in Ayurveda but the concept of Dushi Visha resulted by Virudha Ahara Sevana substantiate the point. Such abnormal changes lead to Vata-Kapha and Pitta-Vata Prakopa, Rasarakta Dushti and Pranavaha Sroto Dushti. Acharya Vagbhata also opined that Dushi Visha leads to blood vitiated disorders which can be compared with allergic reactions in the body. ${ }^{4}$ All medical disciplines are trying to find ways to fight against such challenging tasks due to the high chance of its recurrence. Hence, it creates a need to search for a simple and effective remedy. Among the various treatment modalities, Nasya is the chief procedure to drain doshas from Sira. ${ }^{5}$ Shunthyaadi Sneha Yoga by the name Shunthyaadi Taila and Shunthyaadi Ghrita in the form of Nasya has been highlighted as a drug of choice for the management of Kshavathu ${ }^{6}$. As Kshavathu is the Pradhana Lakshana of Kshavathu Roga, Nasya has been selected for the present study. Hence to assess and compare the efficacy of Shunthyaadi Taila and Shunthyaadi Ghrita in the form of Nasya the present study has been taken.

\section{MATERIALS AND METHOD:}

A. Patients: The diagnosed patients of Kshavathu Roga were selected from OPD and IPD of the Department of Shalakyatantra. Randomly patient has been enrolled in two groups.

B. Study design: a comparative study with two equal groups. Group-A was treated with Shunthyaadi Taila Nasya and Group-B was treated with Shunthyaadi Ghrita Nasya.

C. Sample size: thirty patients (15 patients in each Group).

D. Posology (Table No.1)

E. Selection of drugs

Table 1: Showing the Posology

\begin{tabular}{|l|l|l|}
\hline & GROUP-A & GROUP-B \\
\hline Name of the Medicine & Shunthyaadi Taila Nasya & Shunthyaadi Ghrita Nasya \\
\hline Duration & Total duration-7 days & Total duration-7 days \\
\hline Dose & Eight drops in each nostril & Eight drops in each nostril \\
\hline
\end{tabular}

Shunthyaadi Taila: $1 / 6^{\text {th }}$ parts of Shunthi, Kushta, Kana, Bilwa Majja, Draksha each were made into Kalka form, to this 1 part of Murchita Tila Taila and
4 parts of Shunthyaadi Kashaya was added and boiled till the product attains Sneha Siddhi Lakshana (Mrudu Paka) $)^{7,8,9}$. 
Table 2: Showing the Ingredients of Shunthyaadi Taila

\begin{tabular}{|l|l|}
\hline Name of the ingredient & Quantity \\
\hline Shunthi & $1 /$ sixth part \\
\hline Kushta & $1 /$ sixth part \\
\hline Kana & $1 /$ sixth part \\
\hline Draksha & $1 /$ sixth part \\
\hline Murchita Tila Taila & $1 /$ sixth part \\
\hline Kashaya of Shunthi, Kustha, Kana, Bilva, Draksha & One part \\
\hline
\end{tabular}

Shunthyaadi Ghrita: $1 / 6^{\text {th }}$ parts of Shunthi, Kushta, Kana, Bilwa Majja, Draksha each were made into Kalka form, to this 1 parts of Murchita Ghrita and 4 parts of Shunthyaadi Kashaya was added and boiled till the product attains Sneha Siddhi Lakshana (Mrudu Paka) $)^{7,8,9}$.

Table 3: Showing the Ingredients of Shunthyaadi Ghrita

\begin{tabular}{|l|l|}
\hline Name of the ingredient & Quantity \\
\hline Shunthi & $1 /$ sixth part \\
\hline Kushta & $1 /$ sixth part \\
\hline Kana & $1 /$ sixth part \\
\hline Bilva & $1 /$ sixth part \\
\hline Draaksha & $1 /$ sixth part \\
\hline Murchita Ghrita & One part \\
\hline Kashaya of Shunthi, Kustha, Kana, Bilva, Draksha & Four parts \\
\hline
\end{tabular}

Intervention: Nasyakarma was done in the morning time, eight drops of each Taila and Ghrita in each nostril was administered.

\section{Methodology:}

Inclusion Criteria:

- Patients between the age group of 16-60 years are selected.

- Patient with the following diagnostic symptoms of Kshavathu Roga they are Kshavathu, Naasasraava, Naasashosha and Naasaanah

- Chronicity less than 5 years.

\section{Exclusion Criteria:}

- Patient age below 16yrs \& above 60yrs.

- Patients contraindicated for Nasyakarma.

- Lactating \& Pregnant women.

- Patients suffering from polyps, DNS requiring surgical intervention.
- Patients suffering from another systemic infectious disease.

Diagnostic Criteria:

The diagnosis was established based on-

1. Clinical features: Kshavathu, Naasasraava, Naasashosha and Naasaanaha.

2. Nasal smear: shows a large number of Eosinophils.

Laboratory investigations:

$\mathrm{Hb} \%$, TC, DC, ESR, AEC and Nasal Smear Test.

Clinical Assessment - Clinical assessment was done before, during \& after the treatment. The sign and symptoms were assessed by adopting a suitable scoring method.

Subjective Criteria:

Grading for Parameters: 
Table 4: Showing the Grading's for parameters for the assessment of Kshavathu

\begin{tabular}{|c|c|c|}
\hline SI No & Symptoms & Gradings \\
\hline \multirow[t]{4}{*}{1.} & \multirow{4}{*}{$\begin{array}{l}\text { Kshavathu } \\
\text { (Sneezing) }\end{array}$} & 0-No Sneezing \\
\hline & & 1- 1-10 Sneezing \\
\hline & & 2- 10-15 Sneezing \\
\hline & & 3- 15-20 Sneezing \\
\hline \multirow[t]{4}{*}{2.} & \multirow{4}{*}{$\begin{array}{l}\text { Naasa Sraava } \\
\text { (Nasal discharge) }\end{array}$} & 0- No discharge \\
\hline & & 1- Occasional Rhinorrhea with a feeling of running nose without visible fluid \\
\hline & & 2-Rhinorrhea with the occasional running nose with visible fluid \\
\hline & & 3-Rhinorrhea with a running nose that needs moping but is controllable \\
\hline \multirow[t]{4}{*}{3} & \multirow{4}{*}{$\begin{array}{l}\text { Naasa Shosha } \\
\text { (Nasal Dryness) }\end{array}$} & 0- No symptom \\
\hline & & 1- Only Shushkata in Nasa without Daha \\
\hline & & 2- Shushkata is associated with mild Daha \\
\hline & & 3- Shushkata in Nasa associated with Notable Daha \\
\hline \multirow[t]{4}{*}{4} & \multirow{4}{*}{$\begin{array}{l}\text { Naasa Anaaha } \\
\text { (Nasal Obstruction) }\end{array}$} & 0 - No obstruction \\
\hline & & 1- Inhalation \& exhalation with effort with a feeling of mild obstruction \\
\hline & & $\begin{array}{l}\text { 2- Inhalation \& exhalation with effort with a feeling of moderate obstruction } \\
\text { Inhalation \& exhalation to be supplemented with mouth breathing }\end{array}$ \\
\hline & & 3- Complete blockage with total mouth breathing \\
\hline
\end{tabular}

\section{Objective Criteria:}

- Nasal Smear Test

Statistical Analysis: (Table No.5,6 \& Graph1)

All the data generated and collected during the study were subjected to statistical analysis. Wilcoxon Signed Rank Test and Paired t-test was applied to evaluate the data within the group. Comparative analysis of the overall effect of the treatments in between the groups was done statistically with MannWhitney Rank Sum Test and student t-test (Independent t-test). Conclusions were drawn based on the effect of therapy. Conclusions were drawn based on the results obtained.

Assessment of the effect of therapy:

On Kshavathu factor: In this present study, Kshavathu was relieved by $89.73 \%$ in group A, $100 \%$ in group B. The results were Significant with 'p' value $<0.05$ statistically, stating that there is a significant difference in efficacy between the groups which can be claimed with $100 \%$ reduction in the symptom of group-B patients and that may be due to the action of Ghrita. But after following up the percentage of improvement reduced in both the groups $(66.65 \%$ in group-A, $78.57 \%$ in groupB) as some of the patients relapsed with 2-3 sneezing coming under grade 1 which is negligible.

On Naasa Sraava factor: In this present study, Naasa Sraava was relieved by $83.32 \%$ in group A, $97.39 \%$ in group B. Even though there is no significant change in between the groups statistically with 'p' value $>0.05$ stating both the groups having equal efficacy. But the percentage of reduction is more in Group B because of the additional effect of Ghrita.

On Naasa Shosha factor: In this present study the percentage of relief in Naasa Shosha observed in group-A was $85.71 \%$, and in group-B was $95.04 \%$. Even though there is no significant change in between the groups statistically with ' $p$ ' value $>0.05$ stating both the groups have equal efficacy. But the percentage of reduction is slightly more in Group B.

On Naasa Anaaha factor: In this present study, Naasa Anaaha was relieved by $72.47 \%$ in groupA and $84.65 \%$ in group B. Even though there is no significant change in between the groups statistically with 'p' value $>0.05$ stating both the groups having equal efficacy. But the percentage of reduction is slightly more in Group B. 
On Nasal Smear Test: In the present study, the test showed a marked reduction of eosinophil count in both groups with a percentage in group A is $92.92 \%$ and, in group B is $96.43 \%$ which is a slightly higher reduction in group B. But statistically, it showed no significant difference in between the groups with ' $p$ ' value $>0.05$ stating both the groups having equal efficacy. Both the groups have managed to reduce the eosinophil count in the nasal mucosa tremendously.

\section{DISCUSSION}

In this study on Kshavathu Roga 30 patients were registered, all thirty patients completed their full course of treatment. Most of the patients were from the age group of 16-35 years. Female patients were more affected with the percentage of $60 \%$ when compared to males with $40 \%$ prevalence. Maximum no. of patients $(43.33 \%)$ was of Vata-Pitta prakruti and $33.33 \%$ were of Vata-Kapha prakruti. This disease has no bar for religion and geographical distribution. Kshavathu can manifest as a separate disease entity and as a symptom of other diseases. By observing classical references, we can say that Kshavathu is Vata-Kapha predominated but in Prakrutavastha. Pitta is the main Dosha to deplete the Vyadhikshamatva. Ushna Guna of Pitta increases Dhatupaka and simultaneously reduces immunity. So, Pitta-Vata also accounts for the manifestation of the disease. Nasya is the chief Shodhana procedure selected because this is a procedure that performs Uttamanga Shuddhi which can expel the vitiated Dosha easily. Shunthyaadi Taila Nasya was administered in Group A and Shunthyaadi Ghrita Nasya was administered in Group B.

Probable Mode of Action: Shunthi is the active drug in $S S Y$ having well established pharmacological action over Kshavathu Roga in both classical reference and modern aspects. It is having Laghu and Snigdha Guna, Ushna Veerya and Madhura Vipaka does Vata-Kaphahara. As per Ashtanga Hrudaya, it is both Bhedana and Graahi which are essential in relieving Kshavathu Roga as Bhedana helps in combating Naasa Anaaha, Kshavathu and Graahi in Naasa
Sraava. 6-gingerol, 6-shogaol a major compound of ginger, suppresses cytokine production for $\mathrm{T}$ cell activation and proliferation, thereby not causing $\mathrm{B}$ cell and mast cell activation and resulting in prevention or alleviation of allergic rhinitis symptoms by establishing anti-allergic action. Kushta having Katu, Tikta Rasa along with Laghu Guna, Ushna Virya and Katu Vipaka does Kapha-Vatajit. It is best Raktashodhaka, which is necessary for combating the origin of Kshavathu. The degranulation of mast cells is prevented by Rakta Shodhana hence there will be the prohibition of releasing histamines, B cells, basophil bound IgE, neutrophil and leukotrienes. These are performed inflammatory mediators and thus there will not be further pathogenesis of the allergic mechanism. Pippali with its Madhura, Katu Rasa, Snighdha Guna, Madhura Vipaka and Anushna Sheeta Virya renders the action Rasayana. In Kshavathu Roga this action is also important for Poshana of Dhatus as there will be continuous Sarana of Dhatus thus compromising immunity. Its Snigdha Guna and Madhura Rasa and Vipaka relieve Naasa Shosha. Bilva is Sangrahika, Deepana Agryam which helps specifically in Kaphashoshana to overcome Naasa Sraava condition so assists in blocking devastation of the Prakruta Dosha and thus renders Rasayana property. Draksha is enriched with Madhuara Rasa and Vipaka, Sheeta Virya, Guru Snigdha Guna increases the Rasayana property. Sara Guna removes the Dushita and Sanchita Doshas from the Srotas and assisted in Samprapti Vighatana enhancing the Srotoshodhana property. Mridurechana Karma of the Draksha rectifies Vimargagamana of Vata Dosha and performs Vatanulomana. It is anti-allergic and increases the local immunity of nasal mucosa.

Taila is the best Vatahara which is the main culprit in Kshavathu Roga. It increases immunity as it is Balya. It smoothens the Srotas with rich Sneha Guna resulting in desensitization of sneezing pathology. It is best Yogavahi in nature augments the action of the ingredients used.

Sarpi is Uttama among all the Snehas because Samskarasyanuvartanat property means it imbibes other 
Gunas of the drug without losing its original qualities. Ghrita has been attributed as "Sahasra Veeryam Vidhibhirghritam Karma Sahasra Krut” substantiates Ghritam Yogavahi in a superior level. It intensifies the drug delivery system inside the body as a vehicle. The lipophilic action of cow's ghee facilitates transportation to a target organ and final delivery inside the cell since the cell membrane also contains lipid. It acts as a carrier of active components to be absorbed across the cell membrane. Being a lipid-soluble drug, the drug when poured through the intra-nasal route achieves a higher concentration in the mucus membrane of the nose and diffuses quickly. The nasal mucosa provides a larger surface area and hence the absorption is faster.

Ghrita is Smriti-Buddhi Vivardhanam implies it modulate the cells in the nasal mucosa to alert its Prajna and thus prevents the Prajnaparadha by the cells. This quality is important in stabilising the hypersensitivity action of the cells in the nasal mucosa to a particular external stimulus. By this Prajnabodhita cells increase the transcription of antiinflammatory genes and of genes encoding proteins that have inhibitory effects on transcription of inflammatory and immune genes. This antiinflammatory effect results in modifications to gene transcription occurring via mechanisms known as transactivation or transrepression and this occurs via the suppression of multiple genes that encode inflammatory proteins, a process known as transrepression. This is how the enhancement of immunity establishes inside the cells of the nasal mucosa by Smriti-Buddhi Vivardhana Guna of Ghrita.

NASYAKARMUKATA: Locally Nasya may function as Sravahara, Shothahara, Srothoshodhana. The preoperative procedures like Snehana, Swedana pacify Vatadosha. The main procedure i.e., installation of medicine into the nose acts as Srothoshodhana and it is a way of Vyadhipratyanika chikitsa. The Nasya Dravyas instilled acts by reaching Sringataka Marma. Shringataka Marma includes Srotas where Ghrana, Shrotra and Akshi Tarpana Siras all get united. These Nasya Dravyas increases the general blood circulation, after absorption through the mu- cous membrane. Many nerve endings which are arranged in the peripheral surface of the mucous membrane, olfactory, trigeminal etc. will be stimulated by Nasyadravyas and impulses are transmitted to the C.N.S which leads to the suppression of mediators of allergic response suggesting the action of drugs at cortical levels at the local level. The Hypothalamus induced contraction of smooth muscles secretions of many glands in nasal mucosa will be battled by the Nasyadravyas by reaching higher centres of the brain. This also results in better blood circulation and nourishment of the sense organs. Some local action has also been observed as there was reduction in the symptoms during the treatment period. The postoperative procedures like Kavala, Gandoosha acts as Sleshmahara, Sravahara. Modern science says any lipid-soluble substance has greater chance for passive absorption directly through the olfactory cell of the lining membrane in the nasal mucosa. The cilia of the olfactory cells and the portions of the body of the olfactory cells contain enormous quantities of lipid materials. Non- polar hydrophobic molecules diffuse through the lipid bilayer of the plasma membrane, into and out of cells. Such molecules include oxygen, carbon dioxide and nitrogen gases, fatty acids, steroids, and fat-soluble vitamins. It is a route of absorption of some nutrients and excretion of waste by body cells that are lipid-soluble, and this is performed by Maarjaka karma of the Ghrita. Further drug absorption can also be enhanced by local massage and fomentation. Nasya karma with SSY modifies the inflammatory process by modifying gene expression which results in complex interacts with DNA to form cell regulating proteins. These proteins inhibit leukocyte priming, limit the secretion of cytokines and other mediators, and modulate enzyme systems. They also inhibit the migration of mast cells into the nasal mucosa and induce eosinopenia. Therefore there is remarkable improvement seen in Nasal Smear Test also. In addition to this, on activation of these regulatory proteins and receptors, the muscles contract, constricting blood vessels and allowing less fluid to leak into nasal tissues (oedema) and thus relieving the sensation of nasal congestion. 
Decreased eosinophils and histamines result in antiinflammatory action and capacity to reduce nasal mucosa hyper-reactivity thus desensitizing to sneez- ing. All these beneficiary activities of SSY make its significant efficacy in combating Kshavathu Roga when administered in the form of Nasya.

Table 5: Showing Comparative Statistical Analysis of Parameters

\begin{tabular}{|l|l|l|l|l|l|}
\hline \multirow{2}{*}{ PARAMETER } & \multicolumn{2}{l|l}{ MEDIAN (BT-AT) } & \multicolumn{2}{l|}{ MANN-WHITNEY TEST } & \multirow{2}{*}{ Remarks } \\
\cline { 2 - 6 } & GROUP A & GROUP B & T Value & P-value & \\
\hline KSHAVATHU & 2.000 & 3.000 & 186.000 & $<0.05(0.026)$ & S \\
\hline NAASA SRAAVA & 3.000 & 2.000 & 228.000 & $>0.05(0.854)$ & NS \\
\hline NAASA SHOSHA & 1.000 & 1.000 & 225.00 & $>0.05(0.695)$ & NS \\
\hline NAASA ANAAHA & 2.000 & 1.000 & 265.500 & $>0.05(0.158)$ & NS \\
\hline $\begin{array}{l}\text { NASAL SMEAR } \\
\text { TEST }\end{array}$ & 0.000 & 1.000 & 208.000 & $>0.05(0.261)$ & NS \\
\hline
\end{tabular}

Table 6: Comparative results of group a \& group b on the basis of mean score \& percentage

Characteristics

\begin{tabular}{|c|c|c|c|c|c|c|}
\hline & \multirow{2}{*}{\multicolumn{2}{|c|}{ Mean Score }} & \multirow{3}{*}{ Percentage of Relief } & \multirow{2}{*}{\multicolumn{2}{|c|}{ Mean Score }} & \multirow{3}{*}{$\begin{array}{l}\text { Percentage of } \\
\text { Relief }\end{array}$} \\
\hline & & & & & & \\
\hline & BT & AT & & BT & AT & \\
\hline KSHAVATHU & 2.60 & 0.267 & 89.73 & 2.80 & 0.00 & 100 \\
\hline NAASA SRAAVA & 2.80 & 0.467 & 83.32 & 2.53 & 0.06 & 97.39 \\
\hline NAASA SHOSHA & 1.40 & 0.20 & 85.71 & 1.33 & 0.06 & 95.04 \\
\hline NAASA ANAAHA & 2.66 & 0.73 & 72.47 & 1.73 & 0.26 & 84.65 \\
\hline NASAL SMEAR TEST & 7.53 & 0.53 & 92.92 & 9.33 & 0.33 & 96.43 \\
\hline
\end{tabular}

Graph 1: Showing Comparative Results of Group A and Group B based on Percentage

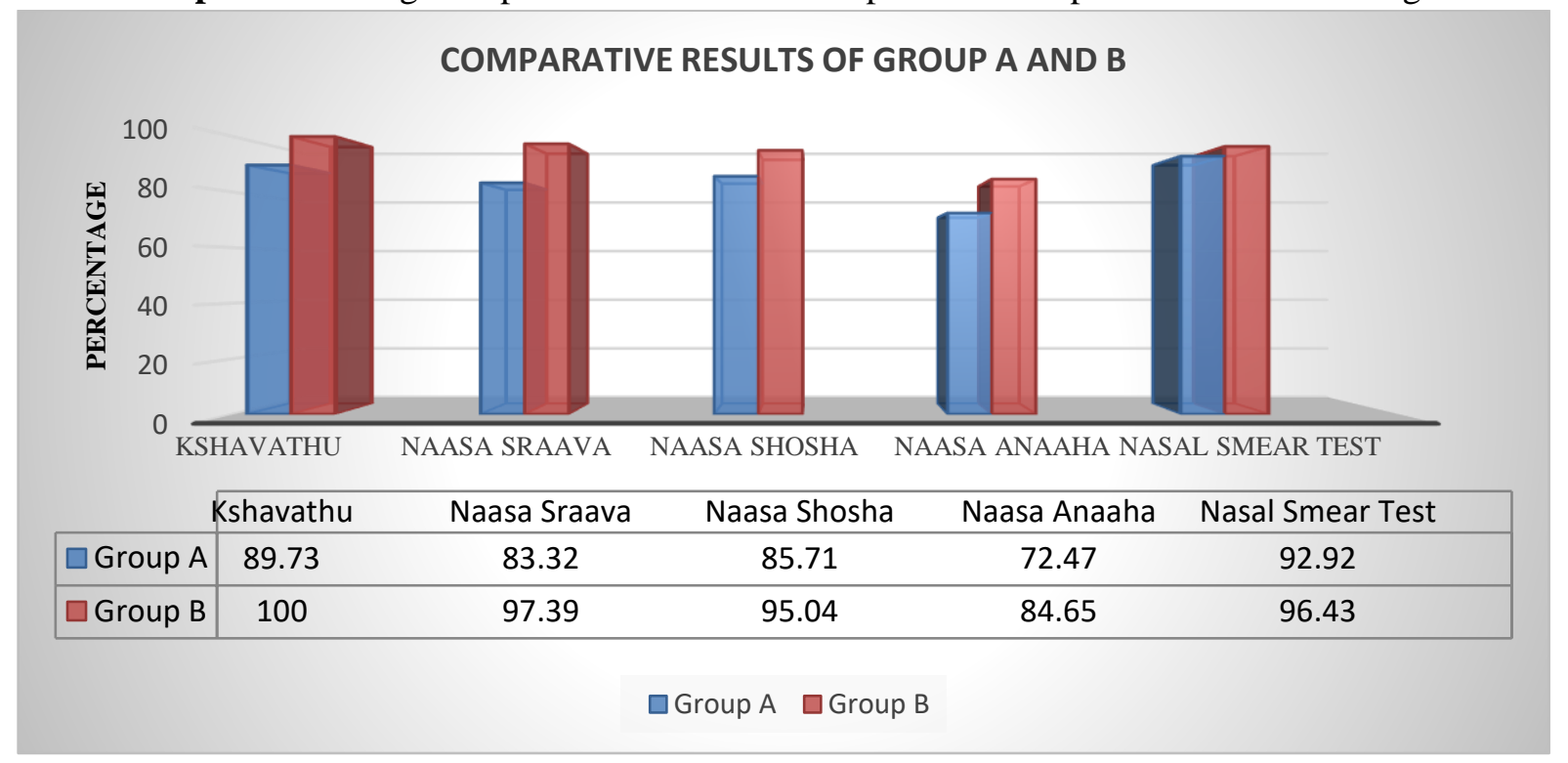

\section{CONCLUSION}

The therapeutic effect of Nasyakarma with Shunthyaadi Taila (Group A) and Shunthyaadi Ghrita (Group B) was found to be beneficial in all the cases of Kshavathu Roga. Both Shunthyaadi Taila Nasya and Shunthyaadi Ghrita Nasya groups showed Highly Significant results when compared within the groups out of five parameters. Only Significant dif- 
ferences in the efficacy of treatments can be seen when compared between the groups over Kshavathu parameter. The rest of the parameters showed nonsignificant results. Hence by comparing the two group's results it can be stated that there is no significant difference in the efficacy of the treatment based on statistical analysis. But by comparing based on the percentage of relief, it can be concluded that Shunthyaadi Ghrita Nasya (Group B) is better than Shunthyaadi Taila Nasya (Group A).

\section{REFERENCES}

1. Dykewicz MS, Hamilos DL: Rhinitis and sinusitis. J Allergy ClinImmunol 2010, 125: S103-15

2. PL Dhingra, Diseases of Ear, Nose and Throat, third edition reprint, Reed Elsevier India Private Limited;2005:204

3. P. Hazarika, D.R. Nayak, R. Balakrishnan (Reprint); Textbook of Ear, Nose, Throat; CBS Publishers \& Distributors Pvt Ltd, 2014; 317

4. Vaidya Yadunandana Upadhyaya Astangahrdayam of Vagbhata edited with the Vidyotini Hindi Commentary by Kaviraja Atrideva Gupta; Chaukhambha Prakashan, Ut. Sthan, 2016; 35/35: 787

5. Hemadri D, Ashtanga Hridaya Sadashiva SP, editors. Varanasi: Chaukhamba Surbharati Prakashana; 2007. Vagbhata. SarvangaSundari Comm. Arunadatta\& Ayurveda Rasayana comm

6. Acharya Chakrapanidatta. Chakradatta. Hindi Commentary by Sri Tripathi Jagadishvaraprasad. Edited by Bhishagratna PT. Mishra Brahmashankara. $4^{\text {th }}$ Edition. Varanasi: Chowkhambha Sanskrit Series Office; 1976, Chapter 58, Verse 10, 465pp.

7. Sharangadhara, Sharangadhara Samhita containing Anjananidana of Maharshiagnivesha, annoted with Dipika Hindi commentary by Tripathi Brahmanand, Varanasi ; Chaukhamba surbharati Prakashan, 2013, Madhyama khanda, 9th Chapter, verse1, 145pp.

8. Ibid, 9th chapter, verse 17, 146pp.

9. Ibid, 9th chapter, verse $6,145 \mathrm{pp}$.

\section{Source of Support: Nil Conflict of Interest: None Declared}

How to cite this URL: Shreeganesh Aithal \& Laxmi. B. Kurle: Comparative Clinical Study Of Shunthyaadi Sneha Yoga Nasya Over Kshavathu Roga W.S.R. To Allergic Rhinitis Based On Sneha Media. International Ayurvedic Medical Journal \{online\} 2021 \{cited October 2021\} Available from: http://www.iamj.in/posts/images/upload/2310_2317.pdf 